\title{
AZ EGYESÜLT ÁlLAMOK ÉS ROMÁNIA KAPCSOLATÁNAK KEZDETEI
}

\author{
The Beginning of US and Romanian relations
}

\section{Kozma Klementina ${ }^{1}$}

\begin{abstract}
Absztrakt: Az Egyesült Államok, mint globális nagyhatalom világszerte kiterjedt nemzetközi kapcsolatokkal rendelkezik. Érdekeinek érvényesítésében pedig nagy szerepet játszik, hogy a világ különböző pontjain jelentős gazdasági és katonai jelenlétet tart fenn. Ezzel szemben a Magyarországgal szomszédos Románia, a világpolitikában kisállamnak minősül. Ugyanakkor nem alábecsülendő, hogy jelentős szerepet játszik Kelet-Közép Európa biztonságának garantálása szempontjából. Magyarország keleti szomszédjaként, illetve NATO és EU szövetséges tagállamként sokkal nagyobb figyelmet érdemel hazai szintéren is, mint amilyet az elmúlt évtizedekben kapott. Egyrészt az említett biztonsági kockázatok kivédésében, másrészt a Magyarországot és Romániát egyaránt érintő vitás és egyéb kérdések kooperatív rendezése végett. Jelen elemzést az elmúlt évtizedekben felélénkült, sikeresnek mondható amerikai-román kapcsolatok eredményei ihlették. A szerzô célja, hogy a teljesség igénye nélkül bemutassa azokat a lényegesnek számító eseményeket, melyek a kapcsolatok fejlődésében kiemelkedő szerepet játszottak.
\end{abstract}

Kulcsszavak: Egyesült Államok, Románia, diplomácia, nemzetközi kapcsolatok

Abstract: The United States as a global power has an extensive international and diplomatic connection around the world. Being able to sustain a major economic and military presence in different regions gives the potential to successfully mobilize efforts in favor of its interests. Therefore, the influence of the United States is based on its economic, military, and not least on its

1 Kozma Klementina a Nemzeti Közszolgálati Egyetem, Amerika Tanulmányok Kutatóintézet tudományos segédmunkatársa, a Hadtudományi Doktori Iskola hallgatója. A szerző további munkásságát lásd a Magyar Tudományos Múvek Tára oldalán: $\underline{\text { https: } / / \mathrm{m} 2 . \mathrm{mtmt} \cdot \mathrm{hu} / \text { gui2 } / \text { ?type }=\text { authors\&mode }=\text { browse\&sel }=10056896}$ 
diplomatic means. In contrast, Romania is a small country in Eastern Europe, but with growing importance on the regional level. As a neighbor of Hungary, a NATO and EU member, Romania deserves more attention than it has received in recent decades. First of all, as the Eastern frontier of the abovementioned organizations, Romania plays an important role to avert security threats coming from outside of the Alliance. also has an importance in the cooperative resolution of issues that are occurring for Hungary and Romania as well. The subject of this paper has been inspired by the results of USRomanian relations that have become more active in the last three decades. The author aims to present those factors that are significant in the relationship between the US and Romania. Bucharest is considered as a stable partner for the US, has an Atlanticist orientation that, if we take it in a broad sense dates back to the 19th century, but if we take it strictly, we can only talk about a partnership after the 1989 regime change.

Keywords: United States, Romania, diplomacy, foreign policy, international relations

\section{BEVEZETÉS}

Történelmi távlatokból nézve az Egyesült Államok és Románia egyaránt fiatal államnak számítanak. Fejlődésüket azonban merőben eltérő tényezők befolyásolták és határozták meg. Míg az 1800-as évek második felére az Egyesült Államokban jelentôs gazdasági fejlődés, teljes mértékű függetlenedés és egységesülés, illetve ipari forradalom zajlott, addig ugyanezen időszak alatt Románia területe két birodalom, az oszmán és orosz hatalmi érdekek ütközőzónájává vált. Az amerikai polgárháború ideje alatt tulajdonképpen még nem is beszélhettünk román államiságról. Az Oszmán Birodalom fennhatósága alá tartozó, de különálló román fejedelemségek, Havasalföld és Moldva 1862-ben kaptak engedélyt a Portától ${ }^{2}$ arra, hogy egyesüljenek. Ezáltal jöhetett a későbbiekben létre Románia. Reménykedve abban, hogy ha közös uralkodója van mindkét fejedelemségnek, akkor érdekeiket jobban tudják érvényesíteni az oszmánokkal szemben, 1859-ben külön-külön megválasztották a moldvai bojár családból származó Alexandru Ioan Cuzat, amely által egy perszonálunió jött létre.

\footnotetext{
2 Porta: az Oszmán Birodalom kormányzata. Forrás: https://www.britannica.com/topic/Sublime-Porte
} 
Cuza nyugatos gondolkodása révén átfogó reformokat próbált megvalósítani, többek között a korra jellemző földreformot, vagyis a feudalizmus felszámolását is. Mindez azonban olyan éles ellenállásba ütközött a román nemesek részérôl, hogy 1866-ban lemondatták tisztségéről, majd száműzték az országból. Helyére még ugyanebben az évben a HohenzollernSigmaringen család sarját, Károly herceget jelölték. ${ }^{3}{ }^{4} \mathrm{Az}$ új uralkodó célkitűzései közé tartozott országának nemzetközi elismertetése, függetlenségének megőrzése és az alkotmányos rend alapjainak megteremtése. ${ }^{5}$ Ugyan a nyugati minták nagy szerepet játszottak az új román állam megteremtésében, de történelmi és kulturális hagyományai merőben eltértek a nyugat-európai államokétól. A román államférfi és esztéta, Titu Maiorescu szavaival élve, Románia egy "alap nélküli forma" (román kifejezéssel: formă fără fond), ami lényegében véve nem mást jelent mint, hogy hiába vette át az ország a nyugati mintákat (például alkotmányos rendszert a belga alkotmány mintájára) ezeknek nem volt sem társadalmi, sem kulturális megalapozottsága a román nép körében. ${ }^{6}$ A hiányosságok ellenére, újonnan létrejött államként kiemelkedő jelentőséget szenteltek a diplomáciai kapcsolatok szélesítésének.

Az Egyesült Államok és Románia gazdasági és kereskedelmi kapcsolatai visszanyúlnak egészen az 1830-as évekig, a román fejedelemségek Konstantinápolytól való elszakadási törekvéseinek kezdetéig. A tényleges diplomáciai kapcsolataik azonban csak jóval későbbre, az 1880-as évekre vezethetőek vissza. A kezdetleges kereskedelmi kapcsolatok ebben az időben még csak a folyami és tengeri kikötők mentére korlátozódtak. A víziszállítmányozás hatékony és viszonylag olcsó megoldásnak számított az árukereskedelemben, de szinte elenyészőnek tekinthető a két ország kapcsolatának viszonylatában. A dobrudzsai területek - melyek a mai Dunadeltát és a tengerparti övezeteket jelentik - az 1878-ban aláírt San Stefano-i béke után váltak elérhetôvé Románia számára, így csak ezt követően lett közvetlen kijárata a Fekete-tengerre. ${ }^{7}$

\footnotetext{
${ }^{3}$ Romania. Forrás: https://history.state.gov/countries/romania

${ }^{4}$ A francia kultúra jelentős hatással volt a XIX. század román politikusaira, többek között az új vezető választására is, hiszen Alexandru Ioan Cuza távozását követően Ion Brătianu előszőr III. Napoleonhoz fordult javaslattételért, aki unokaöccsét, HohenzollernSigmaringen Károly herceget ajánlotta a román trón elfoglalására. Forrás: https://www.newworldencyclopedia.org/entry/Carol I of Romania

${ }^{5}$ COnstantiniu, Florin, 2002.

${ }^{6}$ Constantiniu, Florin, 2002.

${ }^{7}$ The Preliminary Treaty of Peace, San Stefano (1878) - a szerződés az Orosz Birodalom és az Oszmán Birodalom között köttetett.
} 


\section{KAPCSOLATTEREMTÉS}

Az Amerikában zajló események és változások híre, a függetlenségi háború sikeressége, már az 1800-as évek elején eljutott a román fejedelemségekhez is. 1846-ban Simion Bărnuțiu, későbbi '48-as forradalmár munkája révén lefordításra került a Függetlenségi Nyilatkozat, melyet néhány kiváltságos helyzetben levő bojár ${ }^{8}$ is megismerhetett. A Nyilatkozat olyanoknak adott ihletet, mint Mihail Kogălniceanu (1863-1865 között miniszterelnök) és a már korábban említett Titu Maiorescu. A román emigránsok, hasonlóan más európai nemzet fiaihoz, szerepet vállaltak az Államok történelmi eseményeiben, így például a polgárháborúban is. Többek közül említendő a kiemelkedő tehetségű Pomutz György dandártábornok is, ${ }^{10}$ aki azt követően, hogy hôsiesen részt vett a polgárháborúban, magától Rutherford B. Hayes elnöktől kapott kinevezést 1867-ben a szentpétervári konzuli tisztségre, de Pomutz a kinevezést nem vállalta. ${ }^{11}$

Az első amerikai konzult, Henry Romertzet a folyami és tengeri kereskedelem szempontjából egyik stratégiai pontnak számító Galaţi városába delegálták 1858-ban. ${ }^{12}$ Ekkor még mindig csak laza, mondhatni expedíciós szándék jellemezte az amerikai felet, hiszen nagyméretű kereskedelem teremtése nem jött szóba. A kapcsolatok mélyítésének lehetősége és diplomáciai szintre történő emelése Eugene Schuyler nagyköveti kinevezésével vált lehetôvé 1880 júniusában. ${ }^{13}$ Rövid időn belül, a román fél is viszonozta a lépést és Sergiu Voinescu tábornok vezetésével delegációt küldött Washingtonba, hogy képviselje a Román Királyságot, de a román fél részérôl mindez csupán egy ideiglenes látogatásként valósult meg.

Noha az Egyesült Államok a 19. század végén még nem tört világhatalmi pozíciókra, ekkora már jelentős ipari és mezőgazdasági erőre tett szert. Schuyler romániai munkássága kedvezően hatott a kétoldalú kapcsolatokra. Ennek egyik legszembetűnőbb eredménye a kétoldalú

\footnotetext{
${ }^{8}$ Bojár - nemesi származással rendelkező személy román megnevezése.

9 1818. május 31-én született Gyulán, román nemzetiségű családban. Az 1848-49-es magyar szabadságharc honvédszázadosa, később az amerikai polgárháborúban résztvevô tábornok és amerikai diplomata. Forrás: VASVARY, 1939.

10 SASU, 2015.

11 SAUL, N. E., 1996. és Istoria relaţiilor diplomatice ale României cu S.U.A. şi Canada

12 In CELEBration of 125 Years of United StATES AND Romanian DiPLOMATIC RELATIONS, 2006, 2.o.
}

https://photos.state.gov/libraries/romania/231771/PDFs/125years ro-am relations.pdf

${ }_{13}$ Eugene Schuyler (1840-1890) 
kereskedelem támogatását célzó egyezmény megkötése volt. Szerencsétlen egybeesésnek mondható, hogy 1893-ban komoly gazdasági válság ütötte fel a fejét az USA-ban, és a Kongresszus takarékoskodási okokra hivatkozva kénytelen volt lefokozni a bukaresti képviseletet konzuli szintre. Mindezek ellenére 1891 és 1914 közötti időszakban az exportnövekedés mellett, kulturális vonalon is fejlődtek a kapcsolatok. Román művészek előadásai és kiállításai jelentek meg New Yorkban, köztük például George Enescu híres román zeneművész művei is.

\section{A KÉT VILÁGHÁBORÚ HATÁSAI}

A cseh származású amerikai üzletember, Charles J. Vopicka 1913-ban kapott kinevezést a Romániáért, Csehországért és Bulgáriáért felelős nagyköveti teendők ellátására. Tisztségét egészen az első világháború lezárásáig tarthatta meg, mialatt kiemelkedő szerepet játszott azon nemzetek diplomáciai ügyeinek képviseletében és közvetítésében, melyek az OsztrákMagyar Monarchia kötelékei alól szerettek volna függetlenedni. ${ }^{14}$ A háború kitörésekor az addig fő kereskedelmi partnereknek számító európai hatalmak lényegesen csökkentették exportmennyiségüket a kelet-európai államok számára. Néhányan azonban piaci lehetőségeket véltek felfedezni a kialakult helyzetben amerikai és román részről egyaránt. ${ }^{15}$

Kezdetben mindkét állam semlegesként szemlélte a háborús eseményeket és inkább nemzetgazdasági érdekeik megvalósítására összpontosítottak. Annak ellenére, hogy Vopicka aktív közvetítői szerepet igyekezett ellátni, az amerikai döntéshozók mentális térképén még mindig homály övezte Romániárt, révén, hogy nem volt állandó nagyköveti szintű képviseletük Washingtonban. Ugyancsak nehezített a helyzetén, hogy Törökország részvételével az első világháborúban, bezáródtak a tengeri kereskedelmi útvonalak Bukarest számára. ${ }^{16}$ A háborúba 1916. augusztus $27-$ én Erdély megszerzéséért lépett be megtámadva az Osztrák-Magyar Monarchia csapatait a Központi Hatalmak keleti harcvonalán. Ettől kezdve a Román Királyság immáron az antant hatalmak oldalára állva folytatta a háborút. ${ }^{17} \mathrm{Az}$ Egyesült Államok Kongresszusa 1917. április 6-án szintén megszavazta az antant oldalán történő hadbalépést, melynek a háború

\footnotetext{
${ }^{14}$ Charles Joseph Vopicka (1857-1935)

15 LEPCALIUC, 2015.

16 LePCALIUC, 2015. 38.o.

17 WeSTWELL, 2004.
} 
eredményére nézve kiemelkedő jelentősége volt. ${ }^{18}$ Ettől kezdve a két ország szövetségesként vett részt az első világháború további részében.

Noha Bukarest 1917-es, a központi hatalmak általi megszállását követően Vopicka kénytelen volt rövid ideig visszatérni az USA-ba, megbízatását 1920-ig töltötte be. Ezalatt az idő alatt számtalanszor szólalt fel a Kongresszus ülésein a mandátuma alá tartozó államok Osztrák-Magyar Monarchiától történő függetlenedésének előmozdítása érdekében. ${ }^{19}$

A két világháború közötti időszakban a washingtoni izolacionizmus hatására csak mérsékelt ütemben fejlődtek a kapcsolatok. 1926-ban bukaresti székhellyel létrejött "A₹. Egyesült Államok barátai” társaság, melyhez kiemelkedő román mûvészek, diplomaták és politikusok csatlakoztak. A kapcsolatok fejlődését a Ford Motor Társaság bukaresti megjelenése jelezte. A cég 1934-ben először irodát, majd 1936-ban összeszerelő üzemet nyitott a román fôvárosban. ${ }^{20}$

Románia csatlakozása 1941-ben a Tengelyhatalmak oldalán a második világháborúhoz, a két állam diplomáciai kapcsolatainak megszủnésével járt, melyet csak 1946-ban vettek fel újra. A kommunizmus nem kedvezett a bilaterális kapcsolatoknak, de Románia sajátos politikája (Izrael állam elismerése és az 1968-as prágai tavaszból való kimaradása) a tömbön belül lehetôvé tette, hogy kulturális és oktatási területen közeledjen az Államokhoz. 1969-ben Nixon elnök Bukarestbe látogatott, mely példátlanul lendített az együttmúködésen. 1973-ban Nicolae Ceauşescu washingtoni látogatása mintegy előkészítési folyamata volt az 1975-ben megkötésre kerülő kereskedelmi megállapodásnak, mellyel Románia a legnagyobb kedvezményt elnyerő országok státuszába került. Ennek eredményeként Bukarest magánbefektetési és hitellehetőségeket is kapott. Az 1980-as évek közepére azonban a kisebbségek ellen fokozódó elnyomó politikája, illetve az emberi jogok figyelmen kívül hagyása a kedvezményezett országok köréből való kikerüléssel járt. $^{21}$

\section{A RENDSZERVÁLTÁSTÓL NAPJAINKIG}

A kommunizmus bukásával (1989) Románia Nyugat felé fordult mind gazdasági, mind pedig politikai és biztonsági együttműködések tekintetében.

\footnotetext{
18 FEITH, 2017.

${ }^{19}$ In CELEBRATION OF 125 YeARS... Id. mú. 4. o.

${ }^{20}$ In CELEBRATION OF 125 YeARS... Id. mû. 4. o.

${ }^{21}$ In CELEBration OF 125 YeArs... 5. o. Id. mű.
} 
A kezdeti időszak számos szempontból kockázatosnak minősült - ideértve az első demokratikus választásokat, a bányászlázadásokat és a gazdasági reform elindulásának hiányát is - ezért az Egyesült Államok figyelemmel követte az új állami struktúra kialakulását. Az akkori külügyminiszter, James Baker Bukarestbe tett látogatását követően, aggodalmát fejezte ki a választások körül tapasztalt hiányosságokkal kapcsolatban, így fokozott figyelem követte Washingtonban a román belpolitika alakulását. ${ }^{22}$

1992 májusában aláirásra került az Egyesült Államok és Románia kormánya között a kölcsönös befektetések elösegitésérôl és védelméröl szóló szerződés, amely jogi kereteket biztosított a gazdasági együttműködés fellendülésének. Románia volt a harmadik közép-kelet-európai ország, akivel ilyen megállapodást kötött az Egyesült Államok. A sorban megelőzte Lengyelország (1990) és Csehszlovákia (1991). Ezek a kétoldalú szerződések leginkább azt a célt szolgálták a kilencvenes évek elején, hogy alapot teremtsenek a piacgazdaság kialakításához és megfelelő kereteket adjanak az Egyesült Államok befektetési törekvéseinek. Az 1992-ben létrejött szerződés alapján Románia a Kongresszus egyetértésével 1993-tól visszakerülhetett a legkedvezményezettebb államok körébe (angol elnevezés: most-favored-nations, rövidítve: MFN). ${ }^{23}$ A támogatásnak köszönhetően a gazdasági szektor 1996ra teljes piacgazdaságra alakult át, majd egy évvel később Bilaterális Stratégiai Partnerséget kötött Washington és Bukarest, ezzel is elősegítve Románia integrációját az euroatlanti térségbe. ${ }^{24}$ A gazdasági kapcsolatok fejlesztése mellett az Egyesült Államokkal való kapcsolatok mélyítése mögött elsősorban biztonság- és védelempolitikai, illetve külpolitikai okok húzódnak meg. Az említettek mellett napjainkban Románia külpolitikai prioritásainak megfogalmazásakor, kiemelkedően fontos a régió stabilitásának és biztonságának megőrzése, melyet az alábbi szempontok révén szeretne érvényesíteni:

- rakétavédelmi rendszerben való részvétel;

- a NATO és EU biztonságpolitikájának reformja;

- Fekete-tenger- és Duna-stratégia kidolgozása;

- Délkelet-európai vezető állam szerepére való törekvése, kelet európai integráció támogatása és stratégia kidolgozása a Kaszpi-régióra vonatkozóan;

22 In CELEBRATION OF 125 YeARS... 6. o. Id. mű.

23 Romania Bilateral Investment Treaty https://20012009.state.gov/documents/organization/43584.pdf (Letöltés: 2020.11.15.)

${ }^{24}$ BRIEF HISTORY OF THE POLITICAL RELATIONS 
- a Balkán integrációjának elősegítése;

- a Moldovai Köztársasággal való kapcsolatának erősítése, integrációjának támogatása;

- az Egyesül Államokra vonatkozó vízummentesség kiterjesztése román állampolgárok részére is; valamint

- stratégiai jelentőségű katonai támaszpont létrehozása mind az Egyesült Államok, mind pedig a NATO erők számára.

Az 1990-es évek elejétől az Egyesült Államok céljai számos szempontból megegyeztek a felsoroltakkal. A stratégiai partnerség kiindulópontja Bill Clinton 1997. július 11-én tett romániai látogatása és szóbeli nyilatkozata volt, mely az USA és Románia közötti hosszútávú stratégiai partnerségről szólt. Bukarestben tartott beszédében úgy fogalmazott: „Idökö̧̈ben Constantinescu elnök és én megállapodtunk abban, hogy stratégiai partnerséget alakitunk ki a nemzeteink között, egy Amerikának fontos partnerséget, mivel Románia fontos Amerika számára. [...] Együtt segithetünk a stabilitás Románia határain túlnyúló kiterjesztésében, és megmutathatjuk a régió népeinek, hogy van egy jobb út..."25

A Romániával való szorosabb együttmúködés hátterében elsősorban az Egyesült Államokat ért 2001. szeptember 11-i terrortámadás áll. Noha ezt megelőzően, a balkáni háborúk során is támogatásáról igyekezete meggyőzni a román politika az amerikai vezetést, ténylegesen9/11-et követően váltak szorosabbá a kapcsolatok. Románia elhelyezkedésének köszönhetően stratégiai fontossággal bír a NATO keleti határán. A Szövetség céljai között napjainkra nyilvánvalóvá vált, hogy az egyik legfontosabb törekvés egy olyan védelmi vonal létrehozása Románia révén, mely az Oroszországi Föderáció, illetve a Közel-Kelet térségéből érkező fenyegetésekkel szemben képes ellenállni. Románia területén jelenleg hat olyan katonai bázis működik, melyet amerikai erőkkel közösen használ a román haderő. ${ }^{26}$ Egyet pedig teljes mértékben az amerikai erôk üzemeltetnek, mégpedig a Deveşelun található rakétavédelmi bázist. Ezek egyik alapvetô rendeltetése, hogy olyan stabil támaszpontokat nyújtsanak az Egyesült Államok számára, melyekről múveleteket hajthat végre a keleti és közel-keleti térségekre irányulva.

A gazdasági reformok pozitív eredményei és a terrorizmus elleni háborúhoz való hozzájárulás szintén jelentős szerepet játszottak abban, hogy

25 Remarks by PRESident Clinton ANd PRESident Constantinescu to Citizens of ROMANIA, 1997.

26 BOYER, 2018. 
az Egyesült Államok támogatást nyújtson Románia NATO csatlakozásához. A nem hagyományos fenyegetések és kockázatok (terrorizmus, ember- és kábítószerkereskedelem, illegális fegyverkereskedelem, csempészet, gazdasági bűncselekmények stb.) leküzdésének hatékonyabb megvalósítása érdekében 2000. augusztus 24-én az $\mathrm{FBI}^{27}$ megnyitotta bukaresti irodáját. ${ }^{28}$

2011. szeptember 13-án Közös Nyilatkozatot írt alá a két ország, melynek célja a stratégiai, katonai és gazdasági együttmúködés megerősítésére irányult. A dokumentum szélesebb körben sorolja azokat a kulcsfontosságú területeket, melyben az együttmúködést fokozni kívánja mindkét fél:

- a rakétavédelmi rendszer fenntartása és fejlesztése;

- fegyverkereskedelem korlátozása, non-proliferáció, leszerelés;

- terrorizmus elleni küzdelem;

- együttműködés a NATO-n belül;

- technológiai és tudományos együttmúködés, kutató szakemberek cseréjének előmozdítása;

- oktatás és kutatás, személyes kapcsolatokon alapuló szakmai csereprogramok, befektetők, üzletemberek, akadémiai és tudományos kutatást végzők között;

- demokrácia és jogállamiság;

- energiabiztonság és a források diverzifikációja;

- kereskedelem és befektetés; valamint

- regionális együttmúködés és stabilitás. ${ }^{29}$

A nyilatkozatban vállaltak közös erővel történő végrehajtása érdekében egy külön munkacsoportot (angol elnevezéssel: Task Force) hoztak létre, mely évenként ülésezik és értékeli az eredményeket.

A diplomáciai kapcsolatok mellett megtalálhatók az oktatási, kutatási és kulturális területeken zajló együttmúködések is. Az Egyesült Államok kultúrájának, politikai rendszerének és egyéb területeinek szélesebb körű megismerését szolgálja a román felsőoktatás tíz egyetemén elérhető Amerika Tanulmányok szakirány is. ${ }^{30} \mathrm{Az}$ összehangoltabb együttműködés és megjele-

${ }^{27}$ FBI - Federal Bureau of Investigation - Szövetségi Nyomozó Iroda

${ }^{28}$ Forrás: https://ro.usembassy.gov/embassy/bucharest/sections-offices/lawenforcement/

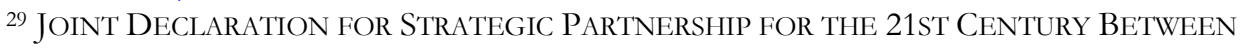
THE UNITED STATES OF AMERICA AND ROMANIA, 2011.

${ }^{30}$ A felsőoktatási intézmények listája a következô: 1) Universitatea Ovidius, Constanţa-Ovidius Egyetem, Konstanca; 2) Universitatea Transilvania, Braşov - Erdélyi Egyetem, Brassó; 3) Universitatea Alexandru I. Cuza, Iaşi - Alexandru Ioan Cuza Egyetem, Jászvásár; 4) Universitatea 
nés érdekében külön szövetséget is létrehoztak erre a célra, nevezetesen az Amerikai Tanulmányok Romániai Szövetségét (román elnevezéssel: Asociaţia de Studii Americane din România). ${ }^{31}$ Amerikai oldalról pedig megtalálható ennek a szövetségnek az ikertestvére, az ún. Románia Tanulmányok. Amerikai Szövetsége néven múködő szervezet. ${ }^{32}$ Ezenkívül érdemes megemlíteni, hogy jelenleg 65 különböző társulat áll rendelkezésére azon románok számára, akik az Egyesült Államokban élnek, vagy ideiglenesen tartózkodnak az országban. Ezek egy része kulturális, oktatási jelleggel bír, más részük pedig kereskedelmi, technológiai kapcsolatok erősítését célozza. ${ }^{33}$

Donald Trump 2016-os megválasztása óta immáron második alkalommal találkozott Klaus Johannis román elnökkel. Első alkalommal 2017. június 9-én Washingtonban, ahol Trump elnök kiemelte, hogy milyen fontosnak tartja a két ország több mint egy évszázados kapcsolatait és a 20 éve fennálló stratégiai partnerséget. Beszédében hosszasan méltatta Romániát, amiért évtizedek óta kiáll a terrorizmus elleni harcban az Egyesült Államok mellett. ${ }^{34}$ Második találkozójukra 2019. augusztus 20-án került sor, szintén Washingtonban. Az időpont választása több szempontból is évfordulónak számított, mivel 30 évvel ezelőtt ért véget a kommunizmus Romániában és 15 éves évfordulóját ünnepelte NATO csatlakozásának. A találkozón Trump elnök mindamellett, hogy méltatta Románia sikeres teljesítményét a védelmi kiadások $2 \%$ os ráfordításával kapcsolatosan, szó esett az egyre növekvő gazdasági kapcsolatok fejlődéséről és energiabiztonsági kérdésekről is. ${ }^{35}$ A Fekete-tenger térségében ugyanis Románia rendelkezik gázlelőhelyekkel, mely kifejezetten előnyös az orosz energiafüggőség alóli mentessülés szempontjából. 2019. november 20-án az Egyesült Âllamok szenátusa új bukaresti nagykövet kinevezését szavazta meg. Adrian Zuckerman román származása révén kiválóan beszél románul, ezért

din București - Bukaresti Egyetem; 5) Universitatea Babeş-Bolyai, Cluj - Bábes-Bólyai Tudományegyetem, Kolozsvár; 6) Universitatea de Vest, Timişoara - Temesvári Nyugati Tudományegyetem; 7) Universitatea din Craiova - Krajovai Tudományegyetem; 8) Universitatea Lucian Blaga, Sibiu - Lucian Blaga Egyetem, Nagyszeben; 9) Universitatea Petru Maior, Tîrgu Mures - Petru Maior Egyetem, Marosvásárhely; 10) Universitatea din Oradea - Nagyváradi Egyetem.

${ }^{31}$ Forrás: https://ro.usembassy.gov/ro/education-culture-ro/studii-americane/

32 The Romanian Studies Association of America. Forrás: http://thersaa.org/

${ }^{33}$ Forrás: https://washington.mae.ro/node/290

34 GARDEN, 2017.

35 President donald J. Trump Is Celebrating Our Strong Partnership with ROMANIA, 2019. 
az amerikai érdekek hatékony megértetésében és a román fél megértésében kulcsfontosságú közvetítő szerepe jut.

\section{KONKLÚZIÓ}

Az Egyesült Államok számára stabil partnernek számító Bukarest atlantista orientációja, ha laza keretek között értelmezzük, egyes elemeiben már a XIX. századra visszanyúlik. Szigorú értelemben viszont csak az 1989es rendszerváltást követően beszélhetünk róla. A román-amerikai kapcsolatok fejlődése jól megalapozott, következetes érdekérvényesítési törekvéseken alapszanak. Mindkét fél kölcsönös előnyökre tehet szert egymás adottságainak hatékony összehangolása révén, így a továbbiakban is erôs együttműködés várható a két állam részéről. Egyrészt Románia földrajzi fekvésével kiváló pozíciót nyújt az Egyesült Államok számára, hogy érdekeit könnyedén érvényesíthesse a régióban. Továbbá stratégiailag kedvező az amerikai erők számára Románia, hiszen a regionális környezetben számos esemény zajlik napjainkban is. Másrészt a román állam amerikai partnere révén nem csak katonai, hanem gazdasági, energetikai és egyéb segítségben részesül. Egyáltalán nem elfelejtendô tényezőnek számít a diplomáciai, oktatási és kulturális kapcsolatok mélyítése sem. Mint azt a tanulmány is jól mutatja, számos intézményben foglalkozik a két ország egymás tanulmányozásával és mélyebb megértésével. Együttműködésüknek sikerét egymás kultúrájának és céljainak minél pontosabb megértése segíti elő. Kapcsolatuk elmélyülése közvetlenül és közvetetten is hatást gyakorol a régió államaira, ezért Románia regionális törekvései felerősödtek.

\section{FELHASZNÁLT IRODALOM}

Boyer, Devin (2018): U.S., Romanian Troops Work Together in Survival Training, U.S. Dept. of Defense. Elérhető: https://www.defense.gov/Explore/News/Article/Article/1614221/usromanian-troops-work-together-in-survival-training/ 2020.11.15.)

BRIEF HISTORY OF THE POLITICAL RELATIONS, EMBASSY OF ROMANIA OF THE UNITED STATES OF AMERICA. Elérhető: https://washington.mae.ro/en/node/534 (Letöltve: 2020.11.15.) 
Charles Joseph Vopicka (1857-1935), Office of the Historian. Elérhető: https://history.state.gov/departmenthistory/people/vopicka-charlesjoseph (Letöltve: 2020.11.15.)

CONSTANTINIU, FlORIN - "O ISTORIE SINCERA A POPORULUi ROMAN", EDITIA A III-A, ED. UNIVERS ENCICLOPEDIC, BUCURESTI, 2002

DANIEL Roxin, Așa arăta harta ideală a României Mari în 1919. Astăzi, s-au dat directive de sus ca la sărbătorirea centenarului să nu se folosească harta României Mari http://www.cunoastelumea.ro/asa-arata-harta-ideala-aromaniei-mari-in-1919-astazi-s-au-dat-directive-de-sus-ca-la-sarbatorireacentenarului-sa-nu-se-foloseasca-harta-romaniei-mari/

Eugene SCHuyler (1840-1890), OfFice OF THE Historian. Elérhető: https://history.state.gov/departmenthistory/people/schuyler-eugene (Letöltve: 2020.11.15.)

FEDERAL BUREAU OF INVESTIGATION. Elérhető: https://ro.usembassy.gov/embassy/bucharest/sections-offices/lawenforcement/ (Letöltve: 2020.11.15.)

FEITH LÁSzLÓ (2017): Az USA hadba lép, Honvédelem.hu. Elérhető: https://honvedelem.hu/hatter/multidezo/az-usa-hadba-lep.html (Letöltve: 2020.11.15.)

Garden, Rose (2017): Remarks by President Trump and President IOHANNIS OF ROMANIA In JOINT PRESS CONFERENCE, The White House. Elérhető: https://www.whitehouse.gov/briefings-statements/remarkspresident-trump-president-iohannis-romania-joint-press-conference/ (Letöltve: 2020.11.15.)

In CELEBRATION of 125 Years of United States and Romanian Diplomatic Relations. American Cultural Center, Bucharest 2006. Elérhetô: https://photos.state.gov/libraries/romania/231771/PDFs/125years roam relations.pdf (Letöltve: 2020.11.15)

ISTORIA RELAȚIILOR DIPLOMATICE ALE ROMÂNIEI CU S.U.A. ŞI CANADA. Elérhető:

https://www.spiruharet.ro/facultati/riif/orar/78906b3543ef145730bd9 06e661e24ce.pdf (Letöltve: 2020.11.15.)

JOINT DECLARATION FOR STRATEGIC PARTNERSHIP FOR THE 21ST CENTURY BETWEEN THE UNITED STATES OF AMERICA AND ROMANIA BUREAU OF EUROPEAN AND EURASIAN AFFAIRs September 13, 2011.

LePCAliUC, ANAmARIa (2015): Relations between Romania and the US during the Neutrality Years 1914-1916. In. AUDRI, Vol. 8, no 2/2015 
ORGANIZAŢII ROMÂNO-AMERICANE DIN SUA. Elérhető: https://washington.mae.ro/node/290 (Letöltve: 2020.11.15.)

President Donald J. Trump Is CElebrating OUR Strong PARTNERShiP WITH ROMANIA (2019), The White House. Elérhetô: https://www.whitehouse.gov/briefings-statements/president-donald-jtrump-celebrating-strong-partnership-romania/(Letöltve: 2020.11.15.)

REMARKS BY PRESIDENT CLINTON AND PRESIDENT CONSTANTINESCU TO Citizens of Romania, July 11,1997, Romania, The White House, Office of the Press Secretary Elérhetô: https://clintonwhitehouse4.archives.gov/WH/New/Spain/1997071415453.html (Letöltve: 2020.11.15.)

Rita PÁlfi - BeAtrix Asbóth- Shafi MusaddiQue (2019): Diplomatic tensions flare between Romania and Hungary after cemetery incident, Euronews.

Elérhetô: https://www.euronews.com/2019/06/07/romanian-crowd-break-intoaustro-hungarian-world-war-i-graveyard (Letöltve: 2020.11.15.)

ROMANIA BILATERAL INVESTMENT TREATY. Elérhető: https://20012009.state.gov/documents/organization/43584.pdf (Letöltve: 2020.11.15.)

ROMANIA. Elérhető: https://history.state.gov/countries/romania (Letöltve: 2020.11.15.)

ROMÂNIA MARE IN REPREZENTĂRI CARTOGRAFICE. Elérhetô: https://www.mapn.ro/cpresa/16086 Romania-Mare-in-reprezentaricartografice (Letöltve: 2020.11.15.)

SASU, AUREL (2015): Un general de brigadă român în războiul civil american (1861-1865) Editura: Şcoala Ardeleană, Cluj Napoca, Preface

Saul, N. E. (1996): Concord and conflict: the United States and Russia, 18671914(Vol. 11). University Press of Kansas.

STUDII AMERICANE. Elérhető: https://ro.usembassy.gov/ro/educationculture-ro/studii-americane/ (Letöltve: 2020.11.15.)

The Preliminary Treaty of Peace, San Stefano (1878)

The Romanian Studies Association OF America. Elérhető: http://thersaa.org/ (Letöltve: 2020.11.15.)

VASVÁRY, EDMUD (1939): Lincoln's Hungarian heroes; the participation of Hungarians in the Civil War, 1861-1865, Washington, D.C

WeStWell, IAN (2004): World War I.: Day by Day Zenith Imprint, ISBN 1840133627 